Julián Ruiz-Galiana' Pilar De Lucas Ramos² Alejandra Garcia-Botella ${ }^{3}$ Alberto García-Lledó ${ }^{4}$ Javier Gómez-Pavón ${ }^{5}$ Juan González del Castillo ${ }^{6}$ Teresa HernándezSampelayo ${ }^{7}$ Mari Cruz Martín-Delgado ${ }^{8}$ Francisco Javier Martín Sánchez ${ }^{9}$ Manuel Martínez-Sellés ${ }^{10}$ José Maria Molero Garcia ${ }^{11}$ Santiago Moreno Guillén ${ }^{12}$ Fernando RodríguezArtalejo ${ }^{13}$ Rafael Cantón ${ }^{14}$ Emilio Bouza ${ }^{15}$

\section{Persistence and viability of SARS-CoV-2 in primary infection and reinfections}

\author{
${ }^{1}$ Internal Medicine Service. Ruber International Hospital. Madrid. \\ ${ }^{2}$ Emeritus. Pneumology Service. Gregorio Marañón General University Hospital, Complutense University. Madrid \\ ${ }^{3}$ General Surgery Service. San Carlos University Clinical Hospital. Complutense University. Madrid. \\ ${ }^{4}$ Cardiology Service. Prince of Asturias Hospital. University of Alcalá. Madrid. \\ ${ }^{5}$ Geriatrics Service. Central Hospital of the Red-Cross. Alfonso X el Sabio University. Madrid. \\ ${ }^{6}$ Emergency Service. San Carlos University Clinical Hospital. Complutense University. Madrid. \\ ${ }^{7}$ Emeritus, Pediatrtics and ACES Service. Gregorio Marañón General University Hospital, Complutense University. Madrid. \\ ${ }^{8}$ Intensive Medicine Service. Torrejón University Hospital. Francisco de Vitoria University. Madrid. \\ ${ }^{9}$ Geriatrics Service. San Carlos University Clinical Hospital. Complutense University. Madrid. \\ ${ }^{10}$ Cardiology Service. Gregorio Marañón General University Hospital, European University. Madrid. \\ ${ }^{11}$ Family Medicine. Infectious diseases. Madrid. \\ ${ }^{12}$ Infectious Diseases Service. Ramón y Cajal Hospital. University of Alcalá de Henares. Madrid. \\ ${ }^{13}$ Department of Public Health. Autonomous University. Madrid. \\ ${ }^{14}$ Microbiology Service. Ramón y Cajal Hospital and Ramón y Cajal Institute for Health Research (IRYCIS). Spanish \\ Network for Research in Infectious Pathology (REIPI). Madrid. \\ ${ }^{15}$ Clinical Emeritus, Community of Madrid. Clinical Microbiology and Infectious Diseases Service of the Gregorio \\ Marañón General University Hospital, Complutense University. CIBERES. Cyber of Respiratory Diseases. Madrid.
}

Article history

Received: 16 September 2021; Accepted: 9 October 2021; Published: 18 October 2021

\section{ABSTRACT}

Since the beginning of the SARS-CoV-2 epidemic, virus isolation in the infected patient was only possible for a short period of time and it was striking that this occurred constantly and did not provide guidance on the clinical course. This fact led to confusion about the efficacy of some of the drugs initially used, which seemed to have a high efficiency in viral clearance and proved ineffective in modifying the course of the disease. The immune response also did not prove to be definitive in terms of evolution, although most of the patients with very mild disease had a weak or no antibody response, and the opposite was true for the most severe patients.

With whatever the antibody response, few cases have been re-infected after a first infection and generally, those that have, have not reproduced a spectrum of disease similar to the first infection. Among those re-infected, a large number have been asymptomatic or with very few symptoms, others have had a moderate picture and very few have had a poor evolution.

Despite this dynamic of rapid viral clearance, laboratory tests were still able to generate positive results in the recovery of genomic sequences and this occurred in patients who were already symptom-free, in others who were still ill and in those who were very seriously ill. There was also no good correlate.

Correspondence:

Emilio Bouza Servicio de Microbiología Clinica y Enfermedades Infecciosas del Hospital General Universitario Gregorio Marañón, Universidad Complutense. CIBERES. Ciber de Enfermedades Respiratorias. Madrid

E-mail:emilio.bouza@gmail.com

All authors belong to the Scientific Committee on COVID-19 of the Madrid College of Physicians (ICOMEM).
For this reason and with the perspective of this year and the half of pandemic, we compiled what the literature leaves us in these aspects and anticipating that, as always in biology, there are cases that jump the limits of the general behavior of the dynamics of infection in general.

Keywords: COVID-19, Viral dynamics, Viral genetic material recovery, Reinfection, SARS-CoV-2, PCR Persistence

\section{Persistencia y viabilidad de SARS-CoV-2 en la primoinfección y reinfecciones}

\section{RESUMEN}

Desde el inicio de la epidemia por SARS-CoV-2, el aislamiento del virus en el paciente infectado era posible solo durante un periodo corto de tiempo y llamaba la atención que esto ocurría de una manera constante y no orientaba sobre la evolución clínica. Este hecho, indujo a confusión sobre la eficacia de algunos de los fármacos utilizados inicialmente que parecian tener una gran eficiencia en el aclarado viral y que resultaron ineficaces para modificar el curso de la enfermedad. La respuesta inmune tampoco se mostraba definitiva para aventurar la evolución aunque la mayoría de los pacientes que tenian una enfermedad muy leve, tenían una débil o nula respuesta de anticuerpos y en los más graves pasaba lo contrario.

Con cualquiera que haya sido la respuesta de anticuerpos, pocos casos han vuelto a infectarse tras una primo-infección y generalmente, los que lo han hecho, no han reproducido un espectro de enfermedad similar a la primera infección. Entre los re-infectados, gran parte han sido asintomáticos o con 
muy pocos sintomas, otros han tenido un cuadro moderado y muy pocos han tenido mala evolución.

Pese a esa dinámica de rápido aclaramiento viral, las pruebas de laboratorio podian seguir siendo capaces de generar positivos en la recuperación de secuencias genómicas y esto ocurria en pacientes libres ya de sintomas, en otros que seguian enfermos y en los muy graves. Tampoco habia un buen correlato.

Por eso y con la perspectiva de este año y medio de pandemia recopilamos lo que nos deja la literatura en estos aspectos adelantando que, como siempre en biología, existen casos que saltan los límites del comportamiento general de la dinámica de la infección en general.

Palabras clave: COVID-19, Dinámica viral, Recuperación de material genético viral, Reinfección, SARS-CoV-2, Persistencia de PCR.

\section{INTRODUCTION}

Since the beginning of the SARS CoV2 infection pandemic, the scientific world has wondered about the pathogenesis of the disease, the persistence of viable viruses, the duration of transmissibility, and the risk of reinfection. Diagnostic tests based on the presence of nucleic acids persisted positive in some patients for weeks and even months and it took a certain period of time to demonstrate their dissociation with viral viability.

Over time, some unknowns such as those mentioned have been cleared up, but others such as the duration of immunity, vaccine efficacy, the risk of longer-term reinfections and the clinical forms of second infections appear.

The Committee on COVID of the Illustrious College of Physicians of Madrid, has received questions both about the persistence of the viral presence during primary infection and about reinfections that it has tried to answer after multidisciplinary discussions.

This document collects the questions received and the answers that in the current state of knowledge we have been able to offer.

\section{WHAT ARE THE VIRAL DYNAMICS IN PRIMARY SARS-CoV-2 INFECTION AND THE SIGNIFICANCE OF MICROBIOLOGICAL TESTS DURING THE CLINICAL COURSE?}

It is very well documented that, after the acquisition of the virus, the replicative curve and the consequent viral load has a great rise between the second and third day before the onset of symptoms, reaching their zenith immediately before and in the first week of the disease, to decrease in the following days [1-4].

The microbiological data on virus recovery, RNA quantification and pathogenic viability in cell line cultures reflect and are consistent with the transmission capacity and infectivity collected in epidemiological and observational studies during the pandemic $[5,6]$.
The recovery of viable viruses is estimated in 8 days after the onset of symptoms and the rate of RT-PCR cycles that suggest viral viability is estimated in equal or less than 28.

Immunosuppression is a conditioning factor that may prolong this time window, being exceptional in these cases a lapse of more than 20 days $[3,7]$. On the other hand, the clinical severity of the disease conditions the immune response and it is not clear if conditions also the viral dynamics [8].

Forty-four per cent of infections occur before the onset of symptoms [5] and in general, there is no transmission capacity from the tenth day of the onset of the disease. In fact, quarantine recommendations have been made for those infected with this criterion [9]. This does not mean that viral RNA cannot be recovered from organic samples beyond this period.

There are many studies that establish the re-positivity of RT-PCR in recovered patients, even those who had previously made the test negative. In a review of these series [10], figures ranging from $2.4 \%$ to the highest of $69.2 \%$ are given and with intervals from discharge from 1 to 38 days and up to 82 days after the onset of symptoms. The vast majority of patients are asymptomatic, but in some of these studies, up to $44.7 \%$ have some mild symptoms of those related to acute COVID; few have a worse course of the disease and some die [10-12].

The factors that determine this re-positivization (viral genetic material, viable or not), and its meaning (genome remains; viral persistence or even reactivation and finally reinfection) is determined by multiple factors, some of which are independent of the disease proper biology, such as technical errors (false negatives, false positives) and cross reactions with other coronaviruses.

Others depend on the biology of the virus itself, such as the initial viral load $[13,14]$, the possible intermittent excretion or the different persistence time of the new variants [15]. Also, on the type of organic samples analyzed (high or low respiratory secretions, blood, feces) $[4,16]$.

Finally, determining factors of the patient. The immune status is shown as a very determining factor, as well as the medications received and age.

Improving knowledge of the viral dynamics and its modifications with the different variants and with the immune response is essential to be able to speak with greater conviction about persistence, reactivation or recurrence and reinfection and to be able to sustain the quarantine recommendations for patients on recovery of the primary infection in the successive phases of the epidemic.

\section{HOW MUCH AND WHAT DOES REINFECTION WITH SARS-CoV-2 INVOLVE?}

Reinfection, defined as the positivization of the RT-PCR, beyond three months after the primary infection, (definition accepted in the literature) whether with clinical symptoms or not, is another face of the SARS-CoV-2 disease, well documented.

Considering reinfection with a criterion of microbiological as well as clinical certainty, goes beyond simply re-positivizing 
the RT-PCR. It requires demonstrating by genetic sequencing that the first and second episode viruses have a sufficiently different structure from what might be expected based on the mutation rate of the original inoculum. That is, to confirm that we are dealing with a differentiated clone or a phylogenetically different virus. Unviable demonstration in the day-to-day of most healthcare structures [17-20].

We know that with SARS-CoV-2 there is an early drop in antibodies titer, including low or no generation in mild clinical conditions $[13,22]$, although there are more and more studies that measure neutralizing antibodies (anti-S) and provide data on longer duration of these than ordinarily we titrate them in the standard clinical follow-up tests, suggesting that there may be a more durable protection than we initially intuited and more consistent with the reality of the observations $[23,24]$.

Added to this is the large number of patients who passed the primary infection asymptomatic and unnoticed (figures up to 10 times the clinically documented according to serological prevalence studies). Likewise, the casual observation in asymptomatic samples of RT-PCR positivity in subjects who have already passed the disease and are outside the known time frame for viral persistence or its genomic fragments.

In addition to the drip of communication of cases with the certainty of being faced with a different virus, and therefore defining reinfection [25-32], studies are appearing that focus the estimates of reinfection.

There is a Danish series of observational follow-up of a long court of infected with positive RT-PCR in the first months of the pandemic (until June 20), and measure how many of these are re-infected (September to December 20), 0.65\% of them did.

A parallel cohort of not infected in the first wave, positivized up to $3.25 \%$. The work shows that the primary infection generates an important but not total protection [33].

Austria has a retrospective observational epidemiological study along the same lines and, taking into account the weaknesses of these measurements, it gives equivalent figures in a proportion of $0.27 \%$ of reinfections and 2.85 of new infections in the second wave [34].

The British SIREN study performs clinical, serological and microbiological monitoring of two large cohorts of health personnel (younger and with greater exposure). One cohort with proven primary infection and another virgin to the infection. They once again demonstrate accumulated incidences of new infections in similar ratios (0.5\% and 2.2\% respectively). Again, significant protection is evidenced after natural infection, at least up to 5 months, but not complete. The study makes a comparison with what is known about vaccines and equates their protection to that of natural infection [35].

Italy, confirms reinfection rates of $0.31 \%$, with a mean follow-up interval of 230 days, in Lombardy, one of its most severely affected regions at the beginning of the epidemic. This incidence of infection is 13 times lower than that of the virgin population [36].
The United States provides another interstate series, based on a database of 3,257,478 persons with conventional serology performed (11.6\% positive and $88.6 \%$ negative and $0.1 \%$ doubtful) and studies the number of PCR positives at an average follow-up time of 390 days per person and again shows infection rates of $0.3 \%$ for those initially serologically positive and $3 \%$ for those negative [37].

These repeatedly similar figures confirm, with different methodologies, a significant protection at least one year after immunization.

Reinfection considered only from a clinical point of view is a fact that is attended on time and with many probabilities that the frequency with which we see it is much lower than what happens in reality due to considerations of inadvertent disease, both for the first as for the second episode and the demonstrative figures from these observational studies.

The literature recognizes this and there are proposals to diagnose reinfection with clinical criteria [38].

The new variants enter fully into reinfections and their clinical behavior and do so fundamentally due to their higher prevalence in a geographical location and at a specific time. The Marseille series is very demonstrative in this sense, confirming the British variant in reinfection and the initial Wuhan variant in the primary infection of its cases [39].

The biological advantages of infectivity and the possibility of escape from the previous immune response are determining factors, although at the moment the conjecture of laboratory studies of the neutralizing capacity of the sera of convalescent or post-vaccination patients is more than the real epidemiological evidence $[35,40-45]$.

We are already in a time of epidemic, in which it should become mandatory, at least in healthcare environments of medium complexity, to have, together with the RT-PCR positivity, more information on the strains found and the viral load or the cycle threshold obtained. We should process more samples and make a greater clinical, laboratory and immuno-microbiological follow-up of those infected. Naturally in controlled and not indiscriminate studies.

Only then, when we accumulate series with more documentation after the disease produced by the different variants, the immune response to these and after the administration of the different vaccines, can solid conclusions be drawn about the natural history of COVID-19 and the effectiveness of protection.

Now we cannot even ensure that natural infection conditions a greater defense than vaccines for reinfection.

\section{WHAT DOES REINFECTION LOOK LIKE CLINICALLY AND HOW IS THE IMMUNITY?}

There are asymptomatic (most), some mild cases and others more severe than the first episode, even with a fatal evolution $[28,29]$.

The possibility of an inflammatory potentiation mediated by the preexistence of antibodies is once again raised [38]. Im- 
munosuppression is once again an evolutionary risk in reinfection $[29,43]$.

Regarding what we know about the immune status of the reinfected people, in most cases, serologies were not available after the first episode, in others it had become negative even though they had responded. Others had an adequate immune response even with neutralizing antibodies. Not enough information is available regarding specifically this type of anti-S antibodies and their protective quantification criteria.

What seems clear is that practically everyone makes an adequate antibody response in the first week of reinfection and this suggests that there is a cell population with memory that facilitates the rapid response.

In some cases, neutralizing antibodies are measured in the nasopharyngeal mucosa in the first week after reinfection [31].

Epidemiologically, it seems that there is a greater risk of greater exposure, as is the case with health-care workers.

Regarding the transmission capacity of the reinfected people, there is also little epidemiological data that they behave as index cases, although some reappear in small outbreaks.

Therefore, for the purposes of clinical care and protection against transmission, reinfection should be treated in the same way as primary infection.

\section{WHAT CAN BE THE FUTURE OF REINFECTIONS?}

It is possible to speculate on the future evolution of reinfections, but in the light of our current knowledge, we can only assure that in the last months the work on reinfection remains in similar figures to those mentioned and the difference is the time lapse between the first and the second infection. It must be taken into account that there will be a very determining factor and it is the prevalence of the virus in the following months. If it continues to fall, both primary and reinfection will be lower. Vaccines are proving to be effective in this attenuation of the epidemic. The role of viral variants will be decisive because of their prevalence at a given time and their potential role in immune escape. Vaccines will again be essential to curb both aspects.

\section{CONCLUSIONS}

The reproduction dynamics of SARS-CoV-2 in human infection reaches its peak at the beginning of the symptoms of the disease, with a subsequent decrease that makes its transmission to be minimal from the $8^{\text {th }}$ day of the disease.

Viral genome recovery techniques can remain positive for up to three months, being remains unviable for transmission.

During this immediate period after the primary infection, reactivations of symptoms associated with the acute disease are described, including some cases with poor clinical evolution. It is difficult to differentiate what are complications of the initial phase, viral reactivation in its interaction with the infected host or even reinfections.

Re-infection after this three-month period is rare (less than 1\%), but possible, even in the five-month period of greatest protection. All this considering that all our references are produced in the first year of the epidemic.

In general, reinfection is asymptomatic or very benign, but it can behave like the primary infection, be more serious and even fatal.

New variants can change what has already been described. It is probable that doing more extensive microbiological and serological follow-up series to those already infected will show upward the possibility of reinfection.

Serological follow-up studies with measurement of neutralizing antibodies are beginning to appear, which equate the protection of natural infection with that granted by vaccines

\section{FUNDING}

None to declare

\section{CONFLICTS OF INTEREST}

The authors declare no conflicts of interest

\section{REFERENCES}

1. Wölfel R, Corman VM, Guggemos W, Seilmaier M, Zange S, Müller $M A$, et al. Virological assessment of hospitalized patients with COVID-2019. Nature. 2020 May;581(7809):465-469. doi: 10.1038/ s41586-020-2196-x.

2. He $X$, Lau EHY, Wu P, Deng $X$, Wang J, Hao $X$, et al. Temporal dynamics in viral shedding and transmissibility of COVID-19. Nat Med. 2020;26(5):672-675. doi: 10.1038/s41591-020-0869-5.

3. van Kampen JJA, van de Vijver DAMC, Fraaij PLA, Haagmans BL, Lamers MM, Okba $N$, et al. Duration and key determinants of infectious virus shedding in hospitalized patients with coronavirus disease-2019 (COVID-19). Nat Commun. 2021;12(1):267. doi: 10.1038/s41467-020-20568-4.

4. Cevik M, Tate M, Lloyd O, Maraolo AE, Schafers J, Ho A. SARSCOV-2, SARS-COV, and MERS-CoV viral load dynamics, duration of viral shedding, and infectiousness: a systematic review and meta-analysis. Lancet Microbe. 2021 Jan;2(1):e13-e22. doi: 10.1016/ S2666-5247(20)30172-5.

5. Cheng HY, Jian SW, Liu DP, Ng TC, Huang WT, Lin HH; Taiwan COVID-19 Outbreak Investigation Team. Contact Tracing Assessment of COVID-19 Transmission Dynamics in Taiwan and Risk at Different Exposure Periods Before and After Symptom Onset. JAMA Intern Med. 2020;180(9):1156-1163. doi: 10.1001/jamainternmed.2020.2020

6. Kim MC, Cui C, Shin KR, Bae JY, Kweon OJ, Lee MK, et al. Duration of Culturable SARS-CoV-2 in Hospitalized Patients with Covid-19. 
N Engl J Med. 2021;384(7):671-673. doi: 10.1056/NEJMc2027040.

7. Owusu D, Pomeroy MA, Lewis NM, Wadhwa A, Yousaf AR, Whitaker B, et al. Household Transmission Study Team. Persistent SARSCoV-2 RNA Shedding without Evidence of Infectiousness: A Cohort Study of Individuals with COVID-19. J Infect Dis. 2021 Feb 27:jiab107. doi: 10.1093/infdis/jiab107.

8. Legros $V_{1}$ Denolly $S$, Vogrig M, Boson B, Siret E, Rigaill J, et al. A longitudinal study of SARS-CoV-2-infected patients reveals a high correlation between neutralizing antibodies and COVID-19 severity. Cell Mol Immunol. 2021 Feb;18(2):318-327. doi: 10.1038/s41423020-00588-2.

9. CDC. Duration of Isolation and Precautions for Adults with COVID-19. Accessed August 26, 2020, https://www.cdc.gov/coronavirus/2019-ncov/hcp/duration-isolation.htm

10 Dao TL, Hoang VT, Gautret P. Recurrence of SARS-CoV-2 viral RNA in recovered COVID-19 patients: a narrative review. Eur J Clin Microbiol Infect Dis. 2021 Jan;40(1):13-25. doi: 10.1007/s10096020-04088-z.

11. Kang YJ. South Korea's COVID-19 Infection Status: From the Perspective of Re-positive Test Results After Viral Clearance Evidenced by Negative Test Results. Disaster Med Public Health Prep. 2020;14(6):762-764. doi: 10.1017/dmp.2020.168.

12. Gousseff M, Penot P, Gallay L, Batisse D, Benech N, Bouiller K et all. Clinical recurrences of Covid 19 symptoms after recovery: viral relapse, reinfection or inflamatory rebound?. J Infect 2020; 81: 816-846. Doi: 10.1016/j.jin.2020.06.73

13. Zheng J, Zhou R, Chen F, Tang G, Wu K, Li F et al. Incidence, clinical course and risk factors for recurrent PCR positivity in discharged COVID 19 patiens Guangzhou, China: a prospective cohort study. PloS Negl Trop Dis 2020; 14 (8):e0008648. doi: 10.1371/journal. pntd.0008648

14. Guallar MP, Meiriño R, Donat-Vargas C, Corral O, Jouvé N, Soriano $\mathrm{V}$. Inoculum at the time of SARS-CoV-2 exposure and risk of disease severity. Int J Infect Dis. 2020 Aug;97:290-292. doi: 10.1016/j. ijid.2020.06.035.

15. Kissler S, Fauver JR, Mack C, et al. Densely sampled viral trajectories suggest longer duration of acute infection with B.1.1.7 variant relative to non-B.1.1.7 SARS-CoV-2. https://dash.harvard.edu/handle/1/37366884 (Accessed on February 17, 2021).

16. Fontana LM, Villamagna AH, Sikka MK, McGregor JC. Understanding viral shedding of severe acute respiratory coronavirus virus 2 (SARS-CoV-2): Review of current literature. Infect Control Hosp Epidemiol. 2021;42(6):659-668. doi: 10.1017/ice.2020.1273.

17. Callow KA, Parry HF, Sergeant M, Tyrrell DA. The time course of the immune response to experimental coronavirus infection of man. Epidemiol Infect 1990; 105(2): 435-46. doi: 10.1017/ s0950268800048019.

18. Galanti M, Shaman J. Direct Observation of Repeated Infections With Endemic Coronaviruses. J Infect Dis. 2021;223(3):409-415. doi: 10.1093/infdis/jiaa392.

19. Inmunidad del SAR-CovTemperton NJ, Chan PK, Simmons G, et al. Longitudinally profiling neutralizing antibody response to SARS coronavirus with pseudotypes. Emerg Infect Dis 2005; 11(3): 411-

\section{6. doi: 10.3201/eid1103.040906.}

20. Wu LP, Wang NC, Chang YH, et al. Duration of antibody responses after severe acute respiratory syndrome. Emerg Infect Dis 2007; 13(10): 1562-4. doi: 10.3201/eid1310.070576.

21. Rijkers $G$, Murk JL, Wintermans $B$, van Looy $B$, van den Berge $M$, Veenemans J, et al. Differences in Antibody Kinetics and Functionality Between Severe and Mild Severe Acute Respiratory Syndrome Coronavirus 2 Infections. J Infect Dis. 2020; 222(8):1265-1269. doi: 10.1093/infdis/jiaa463

22. Lynch KL, Whitman JD, Lacanienta NP, Beckerdite EW, Kastner SA, Shy BR, et al. Magnitude and kinetics of anti-SARS-CoV-2 antibody responses and their relationship to disease severity. Published online 2020 Jul 14. doi: 10.1093/cid/ciaa979

23. He $Z$, Ren L, Yang J, Guo L, Feng L, Ma C, et al. Seroprevalence and humoral immune durability of anti-SARS-CoV-2 antibodies in Wuhan, China: a longitudinal, population-level, cross-sectional study. Lancet. 2021;397(10279):1075-84. doi: 10.1016/S01406736(21)00238-5.

24. an Elslande J, Gruwier L, Godderis L, Vermeersch P. Estimated halflife of SARS-CoV-2 anti-spike antibodies more than double the half-life of anti-nucleocapsid antibodies in healthcare workers. Clin Infect Dis. 2021 Mar 8:ciab219. doi: 10.1093/cid/ciab219.

25.-. To KK, Hung IF, Ip JD, Chu AW, Chan WM, Tam AR, et al. COVID-19 re-infection by a phylogenetically distinct SARS-coronavirus-2 strain confirmed by whole genome sequencing. Clin Infect Dis. 2020; Aug 25;ciaa1275.doi: 10.1093/cid/ciaa1275.;

26. Van Elslande J, Vermeersch $P$, Vandervoort $K$, Wawina-Bokalanga T, Vanmechelen B, Wollants $E_{1}$ et al. Symptomatic Severe Acute Respiratory Syndrome Coronavirus 2 (SARS-CoV-2) Reinfection by a Phylogenetically Distinct Strain. Clin Infect Dis. 2021 Jul 15;73(2):354-356. doi: 10.1093/cid/ciaa1330.

27. Gupta V, Bhoyar RC, Jain A, Srivastava S, Upadhayay R, Imran M, et al. Asymptomatic reinfection in two healthcare workers from India with genetically distinct SARS-CoV-2. Clin Infect Dis. 2020 Sep 23:ciaa1451. doi: 10.1093/cid/ciaa1451.

28. Tillett RL, Sevinsky JR, Hartley PD, Kerwin H, Crawford N, Gorzalski $A$, et al. Genomic evidence for reinfection with SARS-CoV-2: a case study. Lancet Infect Dis. 2021; 21(1):52-58. doi: 10.1016/S14733099(20)30764-7

29. Mulder M, van der Vegt DSJM, Oude Munnink BB, GeurtsvanKessel $\mathrm{CH}$, van de Bovenkamp J, Sikkema RS, Jacobs EMG, Koopmans MPG, Wegdam-Blans MCA Reinfection of SARS-CoV-2 in an immunocompromised patient: a case report. Clin Infect Dis 2020; Oct 9;ciaa1538. doi: 10.1093/cid/ciaa1538.

30. Lee JS, Kim SY, Kim TS, Hong KH, Ryoo NH, Lee J, et al Evidence of Severe Acute Respiratory Syndrome Coronavirus 2 Reinfection After Recovery from Mild Coronavirus Disease 2019. Clin Infect Dis. 2020 Nov 21:ciaa1421. doi: 10.1093/cid/ciaa1421.

31. Selhorst $P$, Van lerssel $S$, Michiels J, Mariën J, Bartholomeeusen $K_{1}$ Dirinck $E$, et al.. Symptomatic SARS-CoV-2 reinfection of a health care worker in a Belgian nosocomial outbreak despite primary neutralizing antibody response. Clin Infect Dis. 2020 Dec 14:ciaa1850. doi: $10.1093 /$ cid/ciaa1850 
32. To KK, Hung IF, Chan KH, Yuan S, To WK, Tsang DN, et al. Serum Antibody Profile of a Patient With Coronavirus Disease 2019 Reinfection. Clin Infect Dis. 2021 May 18;72(10):e659-e662. doi: 10.1093/cid/ciaa1368.

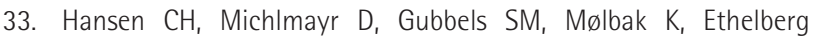
$S$. Assessment of protection against reinfection with SARSCoV-2 among 4 million PCR-tested individuals in Denmark in 2020: a population-level observational study. Lancet. $2021 \mathrm{Mar}$ 27;397(10280):1204-1212. doi: 10.1016/S0140-6736(21)00575-4.

34. Pilz $S$, Chakeri A, loannidis JP, Richter $L$, Theiler-Schwetz V, Trummer $C$, Krause R, Allerberger F. SARS-CoV-2 re-infection risk in Austria. Eur J Clin Invest. 2021 Apr;51(4):e13520. doi: 10.1111/ eci. 13520

35. Hall $V$, Foulkes $S$, Charlett $A$, Atti $A$, Monk EJM, Simmons $R$, et al. Do antibody positive healthcare workers have lower SARSCoV-2 infection rates than antibody negative healthcare workers? Large multi-centre prospective cohort study (the SIREN study), England: June to November 2020 medRxiv preprint doi: 10.1101/2021.01.13.21249642

36. Vitale J, Mumoli N, Clerici P, et al. Assessment of SARS-CoV-2 reinfection 1 year after primary infection in a population in Lombardy, Italy. JAMA Intern Med. Published online May 28, 2021. doi:10.1001/jamainternmed.2021.2959

37. Harvey RA, Rassen JA, Kabelac CA, et al. Association of SARS-CoV-2 seropositive antibody test with risk of future infection. JAMA Intern Med. 2021;181(5):672-679. doi:10.1001/jamainternmed.2021.0366

38. Raveendran AV. COVID 19 re-infection: Diagnostic challenges and proposed diagnostic criteria. Diabetes \&t Metabilic Syndrome: Clinical Research \& Reviews 2021;15:645-648.

39. Brouqui $P$, Colson $P$, Melenotte $C$, Houhamdi $L$, Bedotto $M$, Devaux C, Gautret P, Million M, Parola P, Stoupan D, La Scola B, Lagier JC, Raoult D COVID-19 re-infection. Eur J Clin Invest. 2021 May;51(5):e13537.DOI: 10.1111/eci.13537.

40 Harrington $D$, Kele $B$, Pereira $S$, Couto-Parada $X$, Riddell A, Forbes $\mathrm{S}$, Dobbie H, Cutino-Moguel T. Confirmed Reinfection with SARSCoV-2 Variant VOC-202012/01. Clin Infect Dis. 2021 Jan 9:ciab014. doi: 10.1093/cid/ciab014.

41. Zucman N, Uhel F, Descamps D, Roux D, Ricard JD. Severe reinfection with South African SARS-CoV-2 variant 501Y.V2: A case report. Clin Infect Dis. 2021 Feb 10:ciab129. doi: 10.1093/cid/ciab129

42. Malta Romano C., et al. SARS-CoV-2 reinfection caused by the P.1 lineage in Araraquara city, Sao Paulo State, Brazil. Rev Inst Med Trop Sao Paulo 2021 Apr 23;63: e36. D0I: 10.1590/S16789946202163036. eCollection 2021.

43.- Marquez L, Koy T, Spinler JK, Luna RA, Tocco L, Fasciano L, Dunn J, Campbell JR. Reinfection with Severe Acute Respiratory Syndrome Coronavirus 2 (SARS-CoV-2) B.1.1.7 variant in an immunocompromised adolescent. Infect Control Hosp Epidemiol. 2021 May 3:1-6. DOI: 10.1017/ice.2021.195.

44. Rani PR, Imran M, Lakshmi JV, Jolly B, Jain A, Surekha A, Senthivel $V_{1}$ Chandrasekhar P, Divakar MK, Srinivasulu D, Bhoyar RC, Vanaja PR, Scaria V, Sivasubbu. Symptomatic reinfection of SARS-CoV-2 with spike protein variant N440K associated with immune escape.
S.J Med Virol. 2021 Apr 5. DOI: 10.1002/jmv.26997.

45. Amorim M.R., et al. Respiratory Viral Shedding in Healthcare Workers Reinfected with SARS-CoV-2, Brazil, 2020. Emerg Infect Dis 2021 Apr 19;27(6). DOI: 10.3201/eid2706.210558. 